\title{
Smart specialisations for voivodeships - the first steps toward improvement?
}

\section{Abstract}

The article presents the process and effects of the emergence of smart specialisations in the Silesian and Warmian-Masurian Voivodeships. The starting point is the analysis of smart specialisations in the context of the development theories, which is followed by a discussion of the specialisations of the two voivodeships. This leads to the establishment of several doubts concerning the future situation of the peripheral region presented in the article.

Keywords

Smart specialisation $\cdot$ regional competitiveness $\bullet$ innovation

(C) University of Warsaw - Faculty of Geography and Regional Studies
Wojciech Dziemianowicz'1, Klaudia Peszat ${ }^{2}$

'Department of Local Development and Policy Faculty of Geography and Regional Studies University of Warsaw

e-mail:w.dziemianowicz@uw.edu.pl

2Department of Local Development and Policy

Faculty of Geography and Regional Studies

University of Warsaw

e-mail: k.peszat@uw.edu.pl

Received: 28 October 2013

Accepted: 25 February 2014
Introduction

Times of rising global competition and simultaneous extension of the economic slowdown on global and European markets see the emergence of so-called smart specialisations, which are associated with the prospect of more effective use of limited public funds. This concept is one of the ex-ante conditions set for the regions and countries seeking EU funds in the 2014-2020 perspective $^{1}$. This is why the emergence of smart specialisations is common throughout the Union.

The conviction that the regions should identify and indicate their specialisations by themselves is also dominant in Polish conditions. This is why the voivodeships have independently planned the process of establishing smart specialisations and are currently realising the individual stages, applying various research methods and technologies. Most voivodeships are already in the closing stages of this process. Some have even passed their Voivodeship Development Strategies or Regional Innovation Strategies, which include smart specialisations, but the analyses are still ongoing in certain regions.

However, the greatest regional diversity appears at the definitional level. The rule limiting the number of priorities established by the regions is perceived in different ways (Foray et al. 2012)2. It also seems that most regions use the process approach, but the industries or their groups are also visible in the choices made by the voivodeship self-governments (Strategic Frames 2013).

\footnotetext{
${ }^{1}$ This is an ex-ante condition for pursuing resources for the funding of research and innovation - thematic objective 1

${ }^{2}$ The number of initially defined regional specialisations falls between 2 , as in the case of the Podlaskie Voivodeship, and 10, as in the Opole Voivodeship (Strategic Frames 2013).
}

The article's objective is to provide examples of different approaches in the smart specialisation emergence process and attempt to assess the applied solutions.

The concept of smart specialisation in light of the regional development theories

The concept of smart specialisation is another approach to answering questions about the factors determining regional development. The concept is "entered" in the documents outlining the development of the entire European Union, and is therefore discussed extensively in various political circles, since there is great hope associated with its significant impact on rapid social and economic development, but also in scientific circles - mainly in the context of its "novelty" in relation to the already existing theory (e.g. Słodowa-Hełpa 2013). Numerous elements have been borrowed by the smart specialisation concept from other development concepts and theories (Fig. 1) . $^{3}$

Smart specialisation is strongly based on the assumptions of endogenous development theory, where the internal resources such as entrepreneurs, employees, the local elite, and the relations between them determine the development of a given territorial unit. The relations between the different actors (network cooperation in particular) are playing a greater and greater role in the creation of competitive advantages (see Dziemianowicz \& Szmigiel-Rawska 2010). The issues associated with social capital and trust (Swianiewicz et al. 2008) are also increasingly perceived as factors with a significant impact on regional development, since

${ }^{3} \mathrm{Among}$ others, the regional development theories in Polish literature were reviewed by Gawlikowska-Hueckel (2003) and Dziemianowicz (2008). 


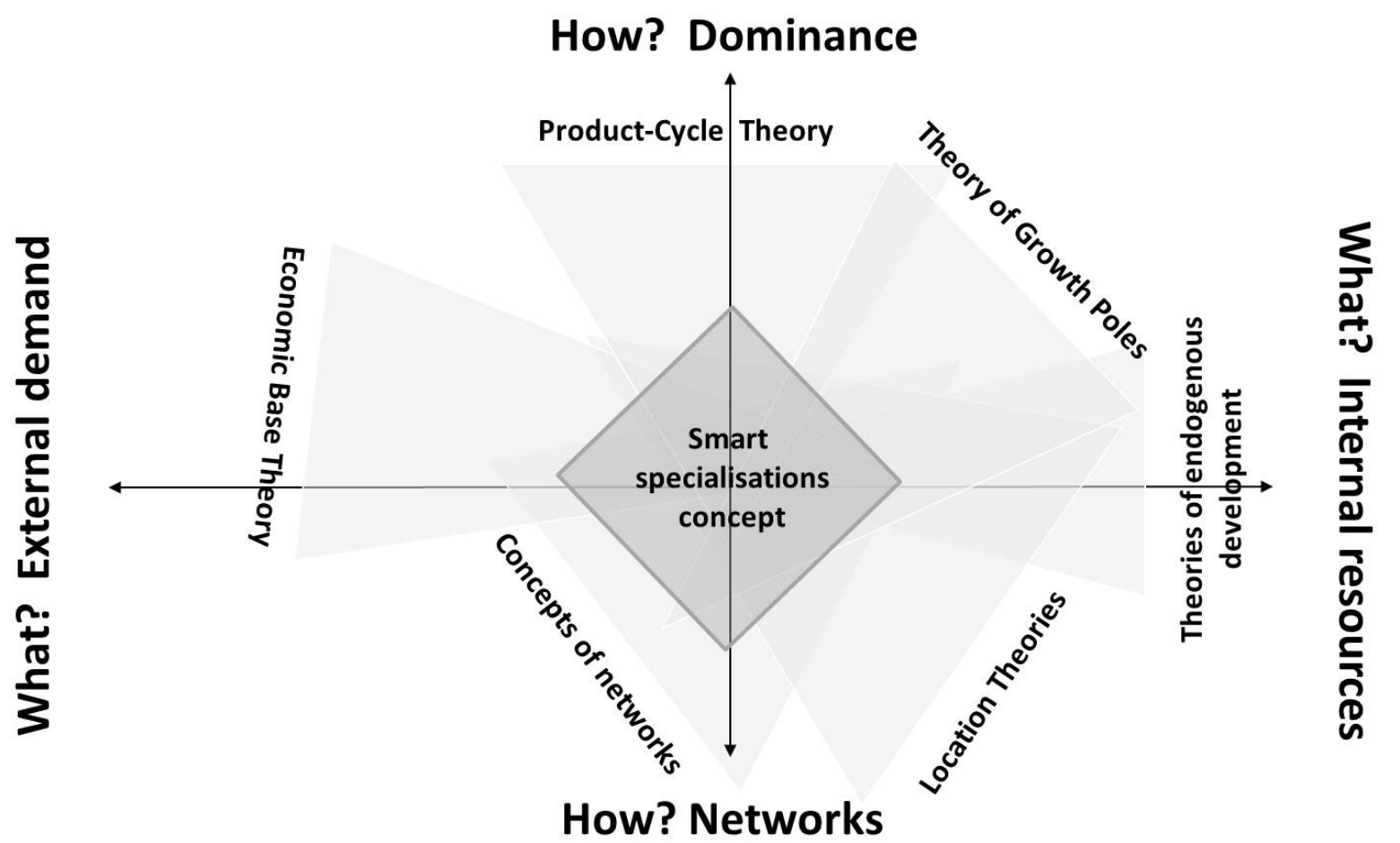

Fig. 1. The four forces of development and smart specialisations concept Source: prepared by the authors based on: Dziemianowicz 2008.

trust-based relations constitute the axis of the creation of cluster structures. In his definition of cluster, M.E. Porter (2001) indicated the neighbour vicinity as beneficial to the establishment of various relations, which in turn translate to a growth in the innovation and competitiveness of such structures.

In turn, spatial specialisation and competitiveness refers to the theory of growth poles, and particularly the theory of industrial district derived from it, according to which the concentration of specialised production plants brings more profit for both individual enterprises and the entire arrangement (see Grzeszczak 1999). This trend also covers the economic base theory, the essence of which is the existence of so-called base industries, which determine the export potential of a given region (Malizia \& Feser 1999). Obviously, specialisation in well-developed goods and the ability to compete on the most demanding markets is highly desirable. Nevertheless, the general abundance of production factors and the ability to achieve relative differences in the production costs of given goods gives territorial units an advantage in competition with others. Therefore, according to Ricardo's theory of comparative costs, the specialisations of countries (regions) are determined by the diverse access of production factors.

One more significant aspect associated with the concept of smart specialisation and referred to by other theories should be noted - innovation. This is at the core of the theories of the product life cycle or growth poles (cf. Grzeszczak 1999; Gawlikowska-Hueckel 2003; Gaczek 2009), but its role in regional development is perceived in different ways by all theories of regional development, as well as increasingly by the regional policy of the European Union (see Szlachta 2009).

The concept of smart specialisation combines various elements of the aforementioned development theories and concepts, but its essence is its foundation on the strong points of the regions and development of competitive advantage on a global scale. According to its principles, resources should be focused on a small number of priorities which already have economic and innovative potential or a potential high enough for the region to create said advantage (Foray 2009). Therefore, the regions should be specialised in the areas in which they are already well-developed, but also seek relations with other areas, expanding their developmental potential (so-called specialisation through diversification, see McCann \& Ortega-Argilés 2011).

Despite the fact that they generally refer to the regional level, the influence of smart specialisation on the growth of competitiveness in supraregional arrangements is obvious, since the establishment of cooperation between regions specialising in the same areas improves competitiveness on the global markets. In turn, cooperation between regions with different specialisations and diverse levels of innovation allows for the development and greater competitiveness of poor regions as well (Camagni \& Capello 2013).

The creation and acceptance of the so-called regional research and innovation strategy for smart specialisation (RIS3) is the practical dimension of the regional implementation of the smart specialisation concept. The European Commission issued the guidelines for these strategies in a handbook entitled Guide to Research and Innovation Strategies for Smart Specialisation (Foray et al. 2012). At a higher level than the previous regional innovation strategies, third-generation strategies focus more on the selection of the fields which are very important to the region, the support of which would entail competitive advantages over other regions. The economic areas (not industries) should be determined through the entrepreneurial discovery of the potential emerging at the contact point of different fields. Taking this into consideration, in contrast to the previous strategies, where the main role in the strategic process was played by public administration (top-down), RIS3 are supposed to be prepared 


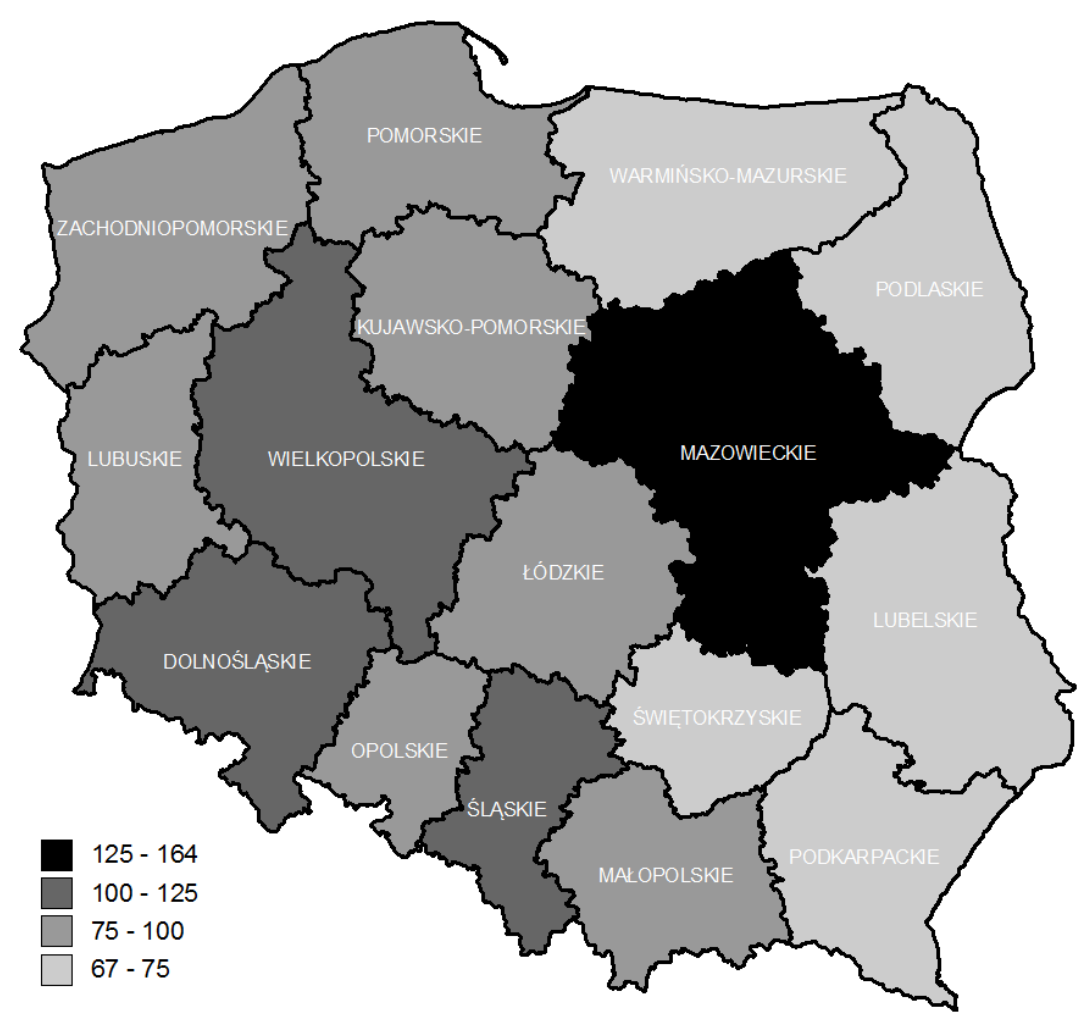

Fig. 2. GDP per capita in the voivodeships in 2011 (Poland $=100)$

Source: prepared by the authors based on Local Data Bank Central Statistical Office.

bottom-up and only be supported by public administration. Therefore, the process of smart specialisation identification and selection should involve the four following actor groups: business, science, administration, and society represented by nongovernment organisations, which combine to form the so-called quadruple helix. The process of establishing smart specialisations and the involvement of the individual actors of regional innovation systems will translate into actual effects, which will be produced by the implementation of the smart specialisation strategies.

The case studies

Differentiated approaches of the voivodeship selfgovernments in the process of establishing smart specialisations will be presented for two examples: the Silesian and WarmianMasurian Voivodeships. The choice of these regions was made on the basis of the level of socio-economic development and the structure of the regional economy.

Silesia is a relatively highly developed region (GDP per capita in 2011 amounted to $108 \%$ of the national average). In turn, Warmia-Mazury belongs to the peripheral regions (GDP per capita in 2011 amounted to only $72 \%$ of the national average) (Fig. 2).

The economic structure of the two voivodeships is also diversified (Table 1). In 2011, the largest share in gross value added in the Silesian Voivodeship was generated by entities conducting industrial activities (a higher result than the national average, 2nd place in the country). Meanwhile, the Warmian-Masurian Voivodeship is characterized by a share of entities conducting business in Section A (mainly in agriculture and forestry) which is much higher than the national average. Undoubtedly, considering such a large degree of economic diversification, the regions require different development strategies.
"Technologies for the economy" - the smart specialisations of the Silesian Voivodeship

The Silesian Voivodeship was one of the first to establish smart specialisations ${ }^{4}$. This process covered the application of various research methods, according to the rule of basing conclusions on statistical and analytical evidence.

The foundations for the establishment of the smart specialisations of the Silesian Voivodeship were the "Technology Development Programme for the period 2010-2020" and the 2006 regional foresight entitled "Priority Technologies for the Sustainable Development of the Silesian Voivodeship", which covered the definition of the so-called technological portfolio of the Voivodeship. The key technologies were classified in four strategic groups according to their co-dependency (insular and nodal technologies) and their impact on regional development (endogenous and exogenous technologies):

A. Nodal and endogenous technologies - technologies based on the internal resources of the region, with a high level of co-dependency on other key technologies, the products of which compete on the external markets;

B. Insular and endogenous technologies - technologies based on the internal resources of the region, with a low level of co-dependency on other key technologies, but competitive enough to conquer global markets;

c. Nodal and exogenous technologies - technologies based on resources outside of the region, with a high level of co-dependency on other regional key technologies, significant for the expansion of regional innovation;

D. Insular and exogenous technologies - technologies based on resources outside of the region, with a low level

${ }^{4}$ The Regional Innovation Strategy for the Silesia Voivodeship for the period 2013-2020 was passed by the Silesian Voivodeship authority on 20 December 2012. 
MISCELLANEA GEOGRAPHICA - REGIONAL STUDIES ON DEVELOPMENT

Vol. $18 \cdot$ No. $1 \cdot 2014 \cdot$ pp. 37-43 • ISSN: 2084-6118 • DOI: 10.2478/mgrsd-2014-0012

Table 1. Gross value added by section groups PKD 2007 in the voivodeships in 2011 (\% of total gross value added)

\begin{tabular}{|c|c|c|c|c|c|c|c|}
\hline Voivodeships & $\begin{array}{l}\text { agriculture, } \\
\text { forestry and } \\
\text { fishing } \\
\text { (section A) }\end{array}$ & $\begin{array}{l}\text { industry } \\
\text { (sections } \\
B, C, D, E)\end{array}$ & $\begin{array}{l}\text { manufacturing } \\
\text { (section } \mathrm{C})\end{array}$ & $\begin{array}{c}\text { construction } \\
\text { (section F) }\end{array}$ & $\begin{array}{l}\text { trade; repair of } \\
\text { motor vehicles; } \\
\text { transportation } \\
\text { and storage; } \\
\text { accommodation } \\
\text { and catering; } \\
\text { information and } \\
\text { communication } \\
\text { (sections } \mathrm{G}, \mathrm{H}, \mathrm{I}, \mathrm{J} \text { ) }\end{array}$ & $\begin{array}{l}\text { financial and } \\
\text { insurance } \\
\text { activities; real } \\
\text { estate } \\
\text { activities } \\
\text { (sections } K, L \text { ) }\end{array}$ & $\begin{array}{c}\text { other services } \\
\text { (sections } \\
M, N, O, P, Q, R, S, T)\end{array}$ \\
\hline DOLNOŚLĄSKIE & 2.1 & 36.8 & 29.2 & 7.2 & 23.2 & 8.9 & 21.9 \\
\hline KUJAWSKO-POMORSKIE & 5.8 & 26.8 & 22.8 & 8.1 & 28.2 & 8.2 & 23.0 \\
\hline LUBELSKIE & 8.7 & 19.7 & 14.7 & 7.6 & 28.4 & 8.9 & 26.8 \\
\hline LUBUSKIE & 4.9 & 30.8 & 24.0 & 7.3 & 26.7 & 8.0 & 22.3 \\
\hline ŁÓDZKIE & 5.2 & 29.3 & 20.2 & 6.9 & 26.6 & 9.9 & 22.0 \\
\hline MAŁOPOLSKIE & 2.2 & 23.1 & 18.7 & 10.3 & 29.9 & 7.6 & 26.8 \\
\hline MAZOWIECKIE & 3.6 & 15.8 & 11.7 & 7.1 & 33.5 & 15.1 & 25.0 \\
\hline OPOLSKIE & 5.7 & 30.1 & 23.4 & 8.2 & 25.6 & 6.8 & 23.7 \\
\hline PODKARPACKIE & 2.5 & 28.3 & 23.4 & 8.7 & 28.7 & 7.0 & 24.9 \\
\hline PODLASKIE & 10.9 & 19.9 & 16.4 & 7.8 & 27.5 & 8.6 & 25.2 \\
\hline POMORSKIE & 3.0 & 25.2 & 21.3 & 8.9 & 30.0 & 9.6 & 23.2 \\
\hline ŚLĄSKIE & 1.0 & 35.3 & 20.9 & 7.8 & 25.9 & 9.7 & 20.3 \\
\hline ŚWIĘTOKRZYSKIE & 5.9 & 26.8 & 19.5 & 9.6 & 28.2 & 6.3 & 23.3 \\
\hline WARMIŃSKO-MAZURSKIE & 8.9 & 24.2 & 20.6 & 8.1 & 25.2 & 8.9 & 24.7 \\
\hline WIELKOPOLSKIE & 5.6 & 27.5 & 23.1 & 8.6 & 29.7 & 7.5 & 21.0 \\
\hline ZACHODNIOPOMORSKIE & 4.1 & 19.1 & 14.6 & 9.8 & 30.7 & 10.2 & 26.1 \\
\hline
\end{tabular}

Source: prepared by the authors based on Local Data Bank Central Statistical Office.

of co-dependency on other regional key technologies, but significant for the expansion of regional innovation (see Table 2).

Next, the regional foresight, industrial foresight and analyses of strategic documents established the eight key technological areas of the Voivodeship: medical technologies (health care), technologies for power engineering and mining, technologies for environment protection, ICT (Information and Communication Technology), material production and processing, transport and transport infrastructure, machinery, motorisation, aviation, and mining industries, as well as nanotechnologies and nanomaterials (Technology Development Programme). These constitute the areas of the Voivodeship's technological specialisation, further specification of which resulted in smart specialisations.

Ultimately, the Regional Innovation Strategy for the Silesia Voivodeship for the period 2013-2020 established the three following fields of smart specialisation:

- $\quad$ power engineering - a specialisation with highly developed infrastructural resources and strong traditions in the region, it already has strong developmental potential, but also requirements in terms of applying innovative technologies, e.g. in the area of renewable energy sources or intelligent technologies of utility distribution networks;

- $\quad$ medicine - due to high innovation level in numerous fields, including the advanced area of diagnostics, but also the treatment of complicated cases, supported with
ICT and solutions in terms of medical engineering and biotechnology, it holds a high position on the national level;

- $\quad$ ICT - the basis of technological, economic, and social development, improves information sharing and provide the entities active in various branches of the economy with opportunities to take part in international cooperation networks.

The Regional Innovation Strategy stresses the thematic dimension of the established smart specialisations. The authors of the Strategy note that the source of such an approach is the inclusion of the actors from various fields in value chains in one thematic area, which is the reason for the smart specialisations focusing around themes rather than industries. Nevertheless, a method strongly based on foresight translates into the final result of this process, which is dominated by the technological understanding of smart specialisations. The established specialisationshaveaveryhighlevelofinnovationandtechnological advancement and simultaneously, with the exception of the ICT specialisation, distinguish the Voivodeship on the national level. ICT includes general purpose technologies, which provide a solid foundation for the development of the entire economy. The use of these technologies must grow in all regions in both technological processes and information transfer, which is to be ensured by the realisation of the Digital Poland Operational Programme and others in the new financial perspective of Polish conditions. This is why the Silesian Voivodeship's choice of ICT as a regional specialisation may raise some concerns. Support for smart specialisations should be provided for areas which 
Table 2. The technological portfolio of the Silesian Voivodeship

\begin{tabular}{|c|c|c|c|}
\hline & & \multicolumn{2}{|c|}{ CO-DEPENDENCE OF THE KEY TECHNOLOGY GROUPS } \\
\hline & & INSULAR TECHNOLOGIES & NODAL TECHNOLOGIES \\
\hline \multirow{2}{*}{ 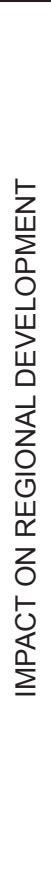 } & 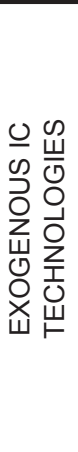 & $\begin{array}{l}\text { Group D } \\
\text { - } \quad \text { Spatial information management technologies } \\
\text { - } \quad \text { Production of non-ferrous metals } \\
\text { - } \quad \text { Polymer products - casting } \\
\text { - } \quad \text { Medical education }\end{array}$ & $\begin{array}{ll}\text { Group C } \\
\text { - } & \text { Biotechnology in environment protection } \\
\text { - } & \text { Technologies for removing problematic } \\
& \text { substances from the ground, water, and sewage } \\
& \text { environments } \\
\text { - } & \text { Dust technologies } \\
\text { - } & \text { Fluid technologies } \\
\text { - } & \text { IT infrastructure technologies } \\
\text { - } & \text { Intelligent transport management system } \\
\text { - } & \text { technologies } \\
\text { - } & \text { ITtelligent information system technologies } \\
\text { - } & \text { Human transport systems }\end{array}$ \\
\hline & 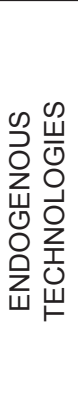 & $\begin{array}{ll}\text { Group B } \\
\text { - } \quad \text { Artificial organs } \\
\text { - } \quad \text { Telemedicine } \\
\text { - } \quad \text { Advanced diagnostic and therapeutic tools } \\
\text { Medical infrastructure technologies and devices }\end{array}$ & $\begin{array}{l}\text { Group A } \\
\text { - } \quad \text { Medical and pharmaceutical biotechnologies, } \\
\text { including biomaterials } \\
\text { - } \quad \text { Environment protection technologies associated } \\
\text { with material engineering } \\
\text { - } \quad \text { Coal gasification technologies } \\
\text { - } \quad \text { Pother power engineering technologies } \\
\quad \text { overpressure and underpressure forming } \\
\text { - } \quad \text { Material engineering in medicine } \\
\text { - } \quad \text { New technical and IT solutions in transport }\end{array}$ \\
\hline
\end{tabular}

Source: The Silesian Voivodeship Technology Development Programme for the years 2010-2020 (The Silesian Voivodeship technology development systemic support programme for the years 2010-2020), 2011, Katowice.

already have sufficient potential (ICT as the subject of research), or fit into certain market niches (specific uses of ICT), allowing them to have an actual positive impact in raising the economic competitiveness of the entire region.

"Innovations for development" - the smart specialisations of the Warmian-Masurian Voivodeship

The process of establishing smart specialisation in the Warmian-Masurian Voivodeship was associated with the development of discussion on the RIS3. In 2010, the Voivodeship Authority passed the Regional Innovation Strategy and, between 2012 and 2013, they updated the Strategy of Social and Economic Development for the Warmian-Masurian Voivodeship until the year 2025. This is why the decision was made to use previous experience and establish the smart specialisations in the general strategic document. Therefore, the process of establishing smart specialisations was a part of the update of the Voivodeship Strategy.

Several questions were asked during the work on smart specialisations, which referred, among others, to the suggestions addressed in the papers of Foray et al. (2012). The answers to the questions produced the following conclusions:

- despite its peripheral nature, the Warmian-Masurian Voivodeship holds relatively well-developed and competitive economic sectors. These sectors have been pointed out in numerous regional studies, including those aimed at preparing all editions of the Regional Innovation Strategy and the Voivodeship Strategy. They include the furniture industry, food production, and yacht and boat production.
- $\quad$ some of the companies active in the leading sectors have created clusters and operate under regional and supraregional cooperation networks ${ }^{5}$. Simultaneously, the entrepreneurs declare the need for support from various public instruments;

- $\quad$ the development of all leading sectors is based on endogenous potential, which includes natural environment conditions and advanced labour culture and tradition;

- $\quad$ the leading sectors are also sectors with high potential for the development of innovation, in both the context of import and the utilisation of the regional scientific and research resources.

The three areas established during the initial work on the Strategy were subjected to discussion with the scientific community and, more importantly, with business representatives. The consultations revealed the desire to expand the specialisation group on the basis of searching for elements common to the initial three areas. This desire came mainly from the communities of the industries, e.g. power engineering, which complies with the trend of "greening up the EU developmental policies," while some of its companies are a part of the power engineering cluster operating within the Pomeranian and Warmian-Masurian Voivodeships. However, arguments relating to the shortage of regional scientific and research resources, with the decisively stronger position of, e.g. the Pomeranian Voivodeship, as well

\footnotetext{
${ }^{5}$ The assessments of the Warmia and Masuria economy dedicate a lot of space to the chemical industry, which is associated mainly with Michelin. However, from the viewpoint of the stimulation of innovation, the creation of corporative bonds, and the support of network cooperation, this company does not show a great interest in the region.
} 


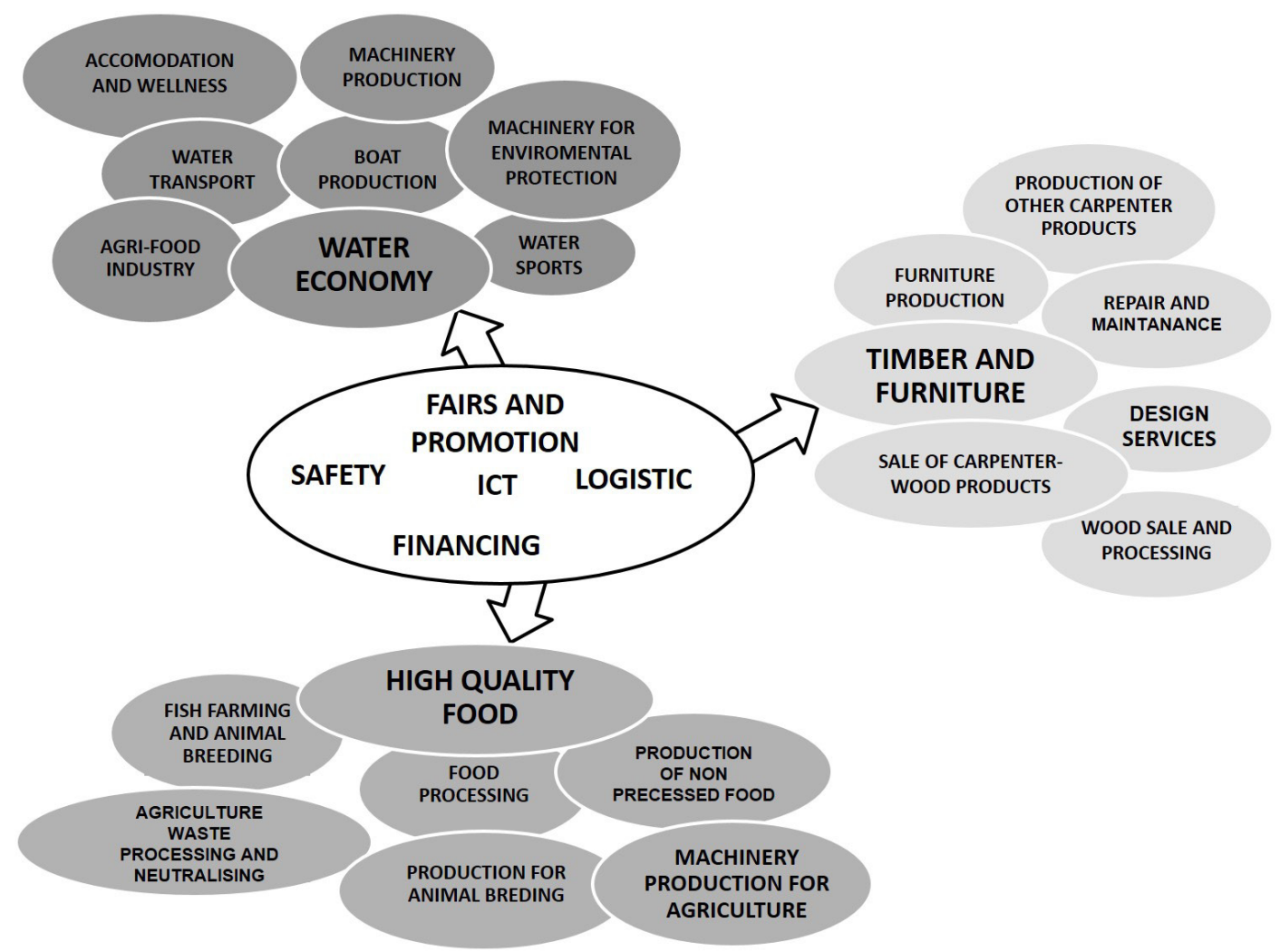

Fig. 3. Smart specialisations of the Warmian-Masurian Voivodeship

Source: prepared by the authors based on the Strategy of Social and Economic Development of Warmian-Masurian Voivodeship up until the year 2025 .

as those indicating the omnipresence of the subject of power engineering, determined the inclusion of this area, but only as a part of the "water economy" specialisation.

The second problem appearing during the consultations was the desire of the industries which deemed themselves as "excluded" to join in. One example is wood joinery companies, which are partially associated with the wood and furniture making industry, but mainly use other materials for their products. The discussions with the enterprises saw the modification of the "timber and furniture" specialisation with this very exception.

Ultimately, the Strategy of Social and Economic Development of the Warmian-Masurian Voivodeship up until the year 2025 lists three specialisations and a "horizontal" area (see Fig. 3):

- $\quad$ water economy, which is based on the sweet water resources (which are exceptional on a national scale and have been included in a specialisation), which will be difficult for Polish competitors to imitate;

- $\quad$ high-quality food, the scientific potential of which is located within the Warmian-Masurian Voivodeship and may also develop in the neighbouring Podlaskie Voivodeship. At the same time, it is obvious that other regions may be inclined toward similar specialisations in the face of health food and healthy lifestyle trends. Nevertheless, it was assumed that it can form a specialisation together with the Podlaskie Voivodeship in relation to Eastern Poland;

- timber and furniture, with the relatively weaker foundation on the regional scientific and research potential, but the advanced furniture making and wood industries operate on the basis of environmental resources. It was assumed that the nature of this specialisation would in fact be supraregional.
The distinction of five "horizontal" areas, which are the foundation for the operations of all regional companies, is also an interesting process. These areas include "logistics", "ICT", "safety", "fairs and promotion" and "financing". The WarmianMasurian Voivodeship does not refer to these areas as specialisations, but they are expected to operate on the basis of innovation, and - particularly in the case of safety - they may be expected to evolve into specialisations (the Voivodeship is the home of the Police Academy in Szczytno - the only such establishment in Poland).

\section{Conclusion}

The concept of smart specialisation is associated with great expectations and concerns. On the one hand, the considerable support of public funds gives hope to entrepreneurs, scientists and representatives of the business community institutions for opportunities to expand and realise their ideas. On the other hand, the concerns are mainly associated with the fate of the economic sectors, which are not considered smart specialisations, but also the doubts concerning the potential of the business/ science relationship. Since the specialisations discussed in the article are based on already welldeveloped areas, where the voivodeships have considerable scientific potential, another doubt may arise, concerning the Warmian-Masurian Voivodeship and other regions considered peripheral. It is hard to imagine that the realisation of the idea of smart specialisations in these regions will provide a significant qualitative change, particularly in such a short time (2014-2020). The growth of funds assigned to economic and scientific purposes concerns all regions; therefore, it will certainly be hard to advance socially and economically in terms of smart development in comparison to those more developed areas. 
However, the likely previously unmatched level of interest of decision makers in support for business/ science/ administration/ community institution relations should definitely be utilised. The first step, the establishment of smart specialisations, will soon be a thing of the past and all interested institutions will have to expand, often beginning to create cooperative relations on a large scale, which seems to be the greatest challenge for the years 2014-2020.

In the context of the development theories, the examples of the two voivodeships presented in the article will certainly be an interesting subject for further research. Both voivodeships are based on their internal resources. The essence of the smart specialisation concept is innovation and competitiveness, as well as intensive relationships with external markets (external demand). The Silesian Voivodeship seems to be trying to move from internal resources to external demand through technological specialisations. In turn, the Warmian-Masurian Voivodeship, as a peripheral region, is likely to develop through a strong network cooperation, which will lead to advances both in terms of innovation and institutional capacity.

\section{References}

Camagni, R \& Capello, R 2013, 'Regional innovation patterns and the EU regional policy reform. Towards smart innovation policies', Growth and Change, vol. 44, no. 2, pp. 355-389.

Dziemianowicz, W 2008, Konkurencyjność gmin w kontekście relacji władze lokalne - inwestorzy zagraniczni, Wydawnictwa Uniwersytetu Warszawskiego, Warszawa.

Dziemianowicz, W \& Szmigiel-Rawska, K 2010, 'Sieci gospodarcze - ujęcie teoretyczne' in Samorząd lokalny w sieciach gospodarczych, eds K Szmigiel-Rawska, W Dziemianowicz \& J Szlachta, WGSR UW, Warszawa, pp. 17-29.

Foray, D 2009, 'Understanding "smart specialisation"' in The question of R\&D specialisation. Perspectives and policy implications, eds D Pontikakis, D Kyriakou \& René van Bavel, Institute for Perspective Technological Studies - Joint Research Centre, Seville, pp. 14-26.

Foray, D, Goddard, J, Beldarrain, XG, Landabaso, M, McCann, P, Morgan, K, Nauwelaers, C \& Ortega-Argilé, R 2012, Guide to research and innovation strategies for smart specialisations (RIS 3), Smart Specialisation Platform S3.

Gaczek, WM 2009, Gospodarka oparta na wiedzy w regionach europejskich, Studia KPZK PAN, t. CXVIII, Warszawa.

Gawlikowska-Hueckel, K 2003, Procesy rozwoju regionalnego w Unii Europejskiej. Konwergencja czy polaryzacja?, Wydawnictwo Uniwersytetu Gdańskiego, Gdańsk.

Grzeszczak, J 1999, 'Bieguny wzrostu a formy przestrzeni spolaryzowanej', Prace geograficzne nr 173, IGiPZ PAN, Wydawnictwo Continuo, Wrocław.

Malizia, EE \& Feser, EJ 1999, Understanding local economic development, Center for Urban Policy Research, Rutgers. The State University of New Jersey, New Jersey.

McCann, P \& Ortega-Argilés, R 2011, Smart specialisation, regional growth and applications to EU cohesion policy, Economic Geography Working Paper 2011. Faculty of Spatial Sciences, University of Groningen.
Porter, ME 2001, Porter o konkurencji, Polskie Wydawnictwo Ekonomiczne, Warszawa.

The Silesian Voivodeship Technology Development Programme for the years 2010-2020 (The Silesian Voivodeship technology development systemic support programme for the years 2010-2020), 2011 [Program rozwoju technologii województwa śląskiego na lata 2010-2020 (Program systemowego wspierania rozwoju technologii województwa śląskiego na lata 2010-2020)], Katowice.

Strategic frames for smart specialisations. Access path, 2013, MRR [typescript][Ramy Strategiczne dla Inteligentnych Specjalizacji. Ścieżka dojścia], Warszawa.

Regional innovation strategy of the Silesia Voivodeship for the years 2013-2020, 2012 [Regionalna Strategia Innowacji Województwa Śląskiego na lata 2013-2020], Urząd Marszałkowski Województwa Śląskiego, Katowice.

Słodowa-Hełpa, M 2013, 'Inteligentne specjalizacje regionów - wyzwania, możliwości i dylematy', Roczniki Nauk Społecznych, t. 41(5), nr 1.

Strategy of social and economic development of WarmianMasurian Voivodeship until the year 2025, 2013 [Strategia rozwoju społeczno-gospodarczego województwa warmińsko-mazurskiego do roku 2025], Olsztyn.

Swianiewicz, P, Herbst, J, Lackowska, M \& Mielczarek, A 2008, Szafarze darów europejskich. Kapitał społeczny a realizacja polityki regionalnej w polskich województwach, Wydawnictwo Naukowe SCHOLAR, Warszawa.

Szlachta, J 2009, 'Kreatywność i innowacyjność polityki spójności Unii Europejskiej w kolejnym okresie programowania po roku 2013' in Kreatywna i innowacyjna Europa wobec wyzwań XXI wieku, eds A Kukliński, K Pawłowski \& J Woźniak, Biblioteka Małopolskiego Obserwatorium Polityki Rozwoju, I tom, Kraków. 